\title{
EFFECT OF rbST ADMINISTRATION ON PUBERTAL AGE AND SOME BLOOD PARAMETERS IN FRIESIAN HEIFERS
}

\author{
Sh. A. Gabr \\ Department of Animal Production, Faculty of Agriculture, University of Tanta \\ Email: (sherifgabr2008@gmail.com)
}

\section{SUMMARY}

To investigate the effect of rbST treatment in relation to some hormones (IGF-I and GH) and metabolites (glucose and urea-N) on the initiation of early puberty in Friesian heifers, a total of 16 Friesian heifers having $187.63 \pm 2.56 \mathrm{~kg}$ live body weight and $8.23 \pm 0.59$ months of age was divided into two similar groups, 8 animals each. Animals in the first group (G1) were subcutaneously (s.c.) injected with saline (0.9\% Nacl) while, animals in the second group (G2) were s.c. injected with $250 \mathrm{mg}$ rbST 14 d-interval for five times pre-puberty. Feeding system and management were the same for both groups. Blood samples were collected to determine concentration of $\mathrm{P} 4, \mathrm{GH}, \mathrm{IGF}-\mathrm{I}$, glucose and urea-N in blood plasma throughout the experimental period from 8.2 mo of age up to puberty. Results show insignificant differences in average P4 concentration during 3 wk pre-puberty, P4 peak pre-puberty and interval from P4 peak to puberty. The interval from $1^{\text {st }}$ rbST injection to puberty was earlier (83.67 vs. $136.0 \mathrm{~d}, \mathrm{P}<0.05)$ and LBW was lighter (254.6 vs. $279.1 \mathrm{~kg}$ ) in G2 than in G1. Concentration of $P 4$ at puberty was not affected by treatment. Average age at puberty was 342 and 391 in $G 2$ and $G 1$, respectively. Overall concentration of $P 4$ during the experimental period was nearly similar in G1 and G2, being 0.460 and $0.472 \mathrm{ng} / \mathrm{ml}$, respectively. Concentration of IGF-I and GH was higher $(P<0.05)$ in G2 than in G1 as overall mean or pre- and at puberty. This increase was about 20 and $19 \%$ for IGF-I and 61 and $41 \%$ for GH pre- and at puberty, respectively. The differences in IGF-I and GH between pre- and at puberty for each group were not significant. Average concentration of IGF-I showed sharp increase post the $1^{\text {st }}$ rbST injection by about $24.5 \%$. Overall concentration of glucose during the experimental period increased $(P<0.05)$ in rbST group $(85.9 \mathrm{mg} / \mathrm{dl})$ as compared to the control group $(79.1 \mathrm{mg} / \mathrm{dl})$, although glucose concentration pre-and at puberty was not affected significantly by rbST treatment. Concentration of urea-N was lower $(P<0.001)$ in $G 2$ than in G1 as overall mean (27.5 vs. $32.2 \mathrm{mg} / \mathrm{dl})$. Also, concentration of urea-N reduced $(P<0.05)$ in $G 2$ compared with G1 pre- and at puberty by 15 and 19\%, respectively. Pre-pubertal urea-N concentration in heifers showed marked reduction by increasing number of injections, in particular post- $1^{\text {st }}$ injection. The strongest positive correlation was between concentration of $G H$ and $I G F-I(r=0.695, P<0.001)$.

In conclusion, rbST treatment at a level of $250 \mathrm{mg}$ at 14-day interval for five successive times pre-puberty is strongly in relation to concentration of GH and IGF-I and in less extend to glucose and urea-N concentration to induce precocious puberty in Friesian heifers

\section{Keywords: rbST, pubertal age, blood parameters, Friesian heifers}

\section{INTRODUCTION}

Administration of exogenous somatotropin (ST) influences the somatotropic axis, improves body weight gain and feed efficiency (Moseley et al., 1992 and Rausch et al., 2002), and increases the number and size of ovarian follicles (Lucy et al., 1994) and growth of corpus luteum and progesterone (P4) production (Gallo and Block, 1991). The somatotropic axis is closely associated with pubertal development in heifers. Chandrashekar et al. (2004) suggested a vital role for GH and IGF-I in the control of pituitary and gonadal functions in animals and humans.

In this respect, Lucy (2000) found that ST and the IGF-I are important hormones for ovarian follicular growth. Receptors of ST and IGF-I are present in follicular cells. In addition, the granulosa and theca cells of the follicle are sites of IGF-I and IGF-II synthesis, respectively. Somatotropin increases ovarian IGF-I synthesis. The IGF is important for follicular growth because both IGF-I and IGF-II are synergistic with gonadotropins for growth and differentiation of ovarian follicles.

The possible involvement of growth hormone (GH) in the regulation of ovarian follicular growth and development in mammals has been suggested by several observations. Therefore, circulating concentrations of $\mathrm{GH}$ increase rapidly during pubertal ages (Ojeda and Jameson, 1977). The effects of ST and IGF-I on the onset of puberty of heifers (195 kg) were studied by Simpson et al. (1991). They proposed that ST and IGF-I are important metabolic mediators involved in the initiation of puberty in heifers.

To identify metabolic hormones that serve as metabolic cues for onset of puberty, Jones et al. (1991) determined changes in GH and IGF-I before puberty in heifers. Frequency of GH release was greater at day -40 to -17 from puberty. Concentrations of IGF-I (measured every $2 \mathrm{wk}$ ) increased linearly $(\mathrm{P}<0.07)$ from day -56 to 0 day 
from puberty. Mejia et al. (1999) suggested that enhanced pre-pubertal IGF-I levels in conjunction with increased pre-pubertal LH levels and pubertal LH pulse amplitude might be involved in the accelerated somatic maturation and in puberty advancement observed in heifers. Somatotropin increased circulating concentration of glucose an effect that may be attributed to increased hepatic gluconeogenesis and reduced uptake of glucose by adipose tissue (Hall et al., 1994).

Aim of the present study was to investigate the effect of $\mathrm{rbST}$ treatment in relation to some hormones (IGF-I and GH) and metabolites (glucose and urea-N) on the initiation of early puberty in Friesian heifers.

\section{MATERIALS AND METHODS}

A total of 16 Friesian heifers having 187.6 \pm 2.56 $\mathrm{kg}$ live body weight and aged 8.2 \pm 0.59 months was divided into two similar groups, 8 animals in each. Animals in the first group (G1) were injected subcutaneously (s.c.) with $2 \mathrm{ml}$ sterilized physiological saline $(0.9 \% \mathrm{Nacl})$ at the same time; animals in the second group (G2) were s.c. injected with $250 \mathrm{mg}$ rbST (Somatech ${ }^{\circledR}$ of Elilly) at intervals of 14 days. The injection started at the 252 days $(8.2$ mo.) for successive five times pre-puberty. All heifers were free of any diseases with healthy appearance and they were housed in separated two groups under semi-open sheds, partially roofed with asbestos.

\section{Feeding system and management}

Heifers in both groups were fed on equal amounts of diet containing the CFM, rice straw and fresh berseem (during winter season) or berseem hay (during summer season) according to the recommendation of the NRC (2001) allowances for growing dairy heifers based on live body weight. Diets were fed to both groups twice daily at eight am. and three pm., while fresh water was available all daytime.

Representative monthly samples of feedstuffs were chemically analyzed for $\mathrm{CP}, \mathrm{CF}, \mathrm{EE}, \mathrm{NFE}$ and ash on DM basis according to the official methods of the A.O.A.C (1995). Chemical composition of CFM, rice straw, fresh berseem and berseem hay used in feeding heifers in both groups is shown in Table (1).

\section{Determenation of puberty}

At the beginning of the ninth month of age, vasoectomized male was introduced to heifers of each group for $20 \mathrm{~min}$. three times daily at 6 and 12 am. and $6 \mathrm{pm}$. to detect heifers exhibiting the $1^{\text {st }}$ oestrous activity. The onset of the $1^{\text {st }}$ oestrus was used as an indicator for the onset of puberty. In addition, ovulatory activity of heifers at puberty was also indicated as P4 concentration exceeded one $\mathrm{ng} / \mathrm{ml}$ for two consecutive sampling days (Jones et al., 1991 and Simpson et al., 1991) in blood plasma collected from heifers during the experimental period. Interval from rbST treatment to heifers reaching puberty was recorded.

Table 1. Chemical analysis of different feed stuffs (on dry matter basis) used in feeding heifers

\begin{tabular}{lllll}
\hline & \multicolumn{4}{c}{ Chemical composition (\%) } \\
\cline { 2 - 5 } Item & CFM & $\begin{array}{l}\text { Rice } \\
\text { straw }\end{array}$ & $\begin{array}{l}\text { Fresh } \\
\text { berseem }\end{array}$ & $\begin{array}{l}\text { Berseem } \\
\text { hay }\end{array}$ \\
\hline $\begin{array}{l}\text { Dry matter, } \\
\text { DM }\end{array}$ & 90.22 & 89.24 & 15.26 & 88.23 \\
$\begin{array}{l}\text { Organic } \\
\text { matter, OM }\end{array}$ & 89.76 & 83.22 & 86.15 & 88.58 \\
$\begin{array}{l}\text { Crude } \\
\text { protein, CP }\end{array}$ & 16.04 & 1.59 & 14.71 & 14.41 \\
$\begin{array}{l}\text { Crude } \\
\text { fiber, CF } \\
\text { ether } \\
\text { extract, EE }\end{array}$ & 10.96 & 37.21 & 24.9 & 24.67 \\
$\begin{array}{l}\text { Nitrogen } \\
\text { free extract, }\end{array}$ & 56.38 & 42.85 & 43.64 & 43.16 \\
$\begin{array}{l}\text { NFE } \\
\text { Ash }\end{array}$ & 10.24 & 16.78 & 13.85 & 11.42 \\
\hline
\end{tabular}

\section{Experimental procedures \\ Blood sampling}

Blood samples were collected from the jugular vein of each animal in both groups starting before rbST treatment and 3-4 day-interval throughout the experimental period (170 days). Blood samples were centrifuged at $3000 \mathrm{rpm}$ for 10 minutes to separate blood plasma and stored at $-20{ }^{\circ} \mathrm{C}$ until analysis.

Concentration of P4 was 3-4 day-interval determined at the beginning of the experiment up to puberty incidence. Throughout the whole experimental period, concentrations of GH and IGF-I were weekly determined and concentration of glucose and urea- $\mathrm{N}$ were monthly determined in plasma.

\section{Hormonal assay}

Direct radioimmunoassay technique (RIA) was performed for determination of plasma P4 concentration using antibody-coated tubes kit (Diagnosis systems, laboratories Texas, USA) according to the procedure outlined by the manufacture. The standard curve of progesterone concentration ranged from 0 to $2.4 \mathrm{ng} / \mathrm{ml}$. The intraand inter-assay coefficients of variation were 5.4 and $9.1 \%$, respectively.

Plasma GH and IGF-I were analyzed by radioimmunoassay. Iodation of $\mathrm{GH}$ and IGF-I and analyses were done according to the procedures previously described by Van Wyk (1983) and Daughaday and Rotwein (1989), respectively. The GH used for analysis was radioimmunoassay-grade. The inter- and intra-assay coefficients of variation for the GH analysis were 11.8 and $5.1 \%$, respectively. Radioimmunoassay grade IGF-I was purchased 
according to manufactory (Thebarton, SA, Australia). The inter- and intra-assay coefficients of variation for the IGF-I analysis were 10.6 and $7.7 \%$, respectively.

\section{Blood biochemical analysis}

Concentration of glucose and urea-N in blood plasma were determined according to Trinder (1969) and Patton and Crouch (1977), respectively, using commercial kits (Diagnostic System Laboratories, Inc USA) and spectrophotometer.

\section{Statistical analysis}

The obtained data were statistically analyzed according to Snedecor and Cochran (1982) and correlation coefficients were determined using SAS (2004) according to the following model: $Y_{i j}=U+$ $A_{i}+e_{i j}$ where: $\mathrm{Y}_{\mathrm{ij}}=$ observed values, $\mathrm{U}=$ overall mean, $\mathrm{A}_{\mathrm{i}}=$ treatment and $\mathrm{e}_{\mathrm{ij}}=$ random error.

\section{RESULTS AND DISCUSSION}

\section{Progesterone profile}

Results presented in Table (2) show insignificant group differences in average $\mathrm{P} 4$ at $3 \mathrm{wk}$ prior to puberty, $\mathrm{P} 4$ peak determined prior to puberty and interval from $\mathrm{P} 4$ peak to puberty incidence. However, the interval from first rbST injection to puberty was significantly $(\mathrm{P}<0.05)$ earlier in $\mathrm{G} 2$ than in $\mathrm{G} 1$, reflecting significantly $(\mathrm{P}<0.05)$ earlier incidence of puberty and insignificantly lighter weight of heifers in G2 than in G1. However, P4 concentration at puberty was not affected by treatment. It is of interest to note that the observed heavier weight of heifers at puberty in G1 was attributed to incidence of earlier puberty in G2 than in G1. Results illustrated in Figure (1) revealed that plasma P4 concentrations were almost higher in treated than in control group at all sampling prepubertal days. Average age of all heifers to attain puberty (progesterone greater than $1 \mathrm{ng} / \mathrm{ml}$ for two consecutive sampling days) was 342 and 391days (11.4 and 13.0 mo of age) in treated and control group, respectively, being lower $(\mathrm{P}<0.05)$ in heifers injected with rbST than in those control group by 49 days $(1.6 \mathrm{mo})$. It is of interest to note that overall concentration of $\mathrm{P} 4$ during the experimental period was nearly similar in both of treated and control group, being 0.472 and $0.460 \mathrm{ng} / \mathrm{ml}$, respectively. These findings proposed that $\mathrm{rbST}$ is important to induce the initiation of puberty in heifers. Similar results were obtained by Simpson et al. (1991) in heifers injected with growth hormone-releasing factor (GRF) and human serum albumin (HAS). Also, Aboul-Wafa (2009) found marked increase in P4 concentration in blood serum of ewes treated with rbST as compared to the controls.

In addition to its known metabolic effects, $\mathrm{GH}$ has been shown to have direct effects on function of ovarian granulose cells in rats and pigs (Hsu and Hammond, 1987 and Adashi et al., 1989). Some studies have shown that GH treatment in vivo can stimulate growth of small follicles in pre-pubertal pigs (Spicer et al., 1990) and increase ovulation rates in cyclic gilts (Kirkwood et al., 1988). The mechanism for the increase in follicular growth and ovulation rate is unclear.

\section{Concentration of IGF-I and GH}

Data in Table (3) show that overall concentration of IGF-I and GH during the experimental period was significantly $(\mathrm{P}<0.001)$ higher in treated than in control groups. Also, concentration of IGF-I and GH pre- and at puberty was significantly $(\mathrm{P}<0.05)$ higher in treated than in control group. This increase was about 20 and $19 \%$ for IGF-I and 61 and $41 \%$ for GH pre- and at puberty, respectively. It is of interest to note that concentration of IGF-I increased at puberty as compared to pre-pubertal values while, GH concentration showed different trend in both groups. However, the differences in IGF-I and GH between pre- and at puberty for each group were not significant.

Results illustrated in Figure (2) reveal that plasma IGF-I concentrations were almost higher in treated than in control group at all sampling prepubertal days. Average concentration of IGF-I showed sharp increase post the $1^{\text {st }}$ injection in treated heifers, resulting in large differences from that in control group by about $24.5 \%$. These differences continued to be present after the subsequent injections, indicating higher pre-pubertal IGF-I concentrations in treated than in control group as affected by rbST injection.

It is worthy noting that $\mathrm{GH}$ concentration showed the same trend of change as IGF-I as affected by rbST injection, but the differences between treated and control group were reduced by increasing number of rbST injections from the $1^{\text {st }}$ one (Figure 3).

In similarity with the present study, Stelwagen et al. (1993) and Slaba et al. (1994) found a 3-7 foldincrease in plasma rbST concentrations during the first three post-injection hours in cows treated with rbST. In the next 8 days, the rbST concentration in rbST treated cows was significantly higher than the controls. Plasma concentration of IGF-I increased nearly 2 folds as early as $24 \mathrm{~h}$ following rbST treatment and then continued to increase by $48 \mathrm{~h}$ post $48 \mathrm{~h}$ injection (4 times higher than controls). From $48 \mathrm{~h}$ after rbST treatment, IGF-I concentrations remained at a plateau till day 11 , then decreased slowly but still remained higher on day 14 than those in controls.

Administration of exogenous bovine $\mathrm{GH}$ stimulates growth in growing cattle, including prepubertal heifers (Sandles and Peel, 1987; McShane et al., 1989 and Vestergaard et al., 1993). Growth 
hormone exerts some of its action via IGF-I, and, consistent with this, the concentration of IGF-I in blood is increased by GH treatment (Crooker et al., 1990). The biological effects of IGF-I are modulated by IGF binding proteins (IGFBP), which have been characterized by legend blotting in calves (Skaar et al., 1994).

The present results indicated the role of $\mathrm{GH}$ and IGF-I that serve as metabolic cues for onset of puberty. The somatotropic axis is closely associated with pubertal development in heifers. Therefore, Chandrashekar et al. (2004) suggested a vital role for GH and IGF-I in the control of pituitary and gonadal functions in animals and humans. In this respect, Schams et al. (1991) observed an increase of plasma rbST at $7 \mathrm{~d}$ after treatment of cows with recombinant Methionyl rbST (500 mg/14 d), and then decreased at $14 \mathrm{~d}(\mathrm{P}<0.01)$. Also, Jones et al. (1991) determined changes in GH, IGF-I and LH before puberty in heifers. They found that frequency of GH release was greater at day -40 than at day -17 of puberty in Angus heifers. In Braford and Charolais heifers, frequency of GH release was greater at day -17 than at day -40 of puberty. Concentrations of IGF-I (measured every $2 \mathrm{wk}$ ) increased linearly $(\mathrm{P}<0.07)$ rom day -56 to 0 day from puberty in Angus but not in other breeds. In addition, enhanced pre-pubertal IGF-I levels in conjunction with increased prepubertal LH levels and pubertal LH pulse amplitude might be involved in the accelerated somatic maturation and in puberty advancement observed in heifers. In this line, Mejia et al. (1999) reported that serum IGF-I level increased from birth to $22 \mathrm{wk}$ of age and then reached a plateau. In agreement with the present results, Hodate et al. (1991) found that plasma IGF-I concentrations were significantly higher in the rbST treated than in the control heifers at pre-pubertal stage. Similar trend was reported in the rbST treated cows (Hodate et al., 1991). Also, treatment with rbST significantly increased IGF-I concentration by $36.7 \%$ (121.2 and $77.6 \mathrm{ng} / \mathrm{dl}$ for rbST and control group, respectively) as reported by Gallo and Block (1990). Moreover, Tripp et al. (1998) found that in heifers and steers, serum ST and IGF-I concentrations increased $(\mathrm{P}<0.05)$ by $\mathrm{ST}$ administration.

Table 2. Average $\mathbf{P 4}$ concentration (ng/ml) during pre-pubertal stage and at puberty, and P4 concentration, age (day) and live body weight (kg) at puberty of Friesian heifers in control (G1) and treated (G2) groups

\begin{tabular}{lcc}
\hline Item & G1 & G2 \\
\hline During pre-pubertal stage: & & $0.64 \pm 0.03$ \\
Average P4 during 3 wk prior to puberty & $0.85 \pm 0.10$ & $0.71 \pm 0.10$ \\
P4 peak prior to puberty & $14.0 \pm 1.86$ & $11.5 \pm 1.86$ \\
Interval from P4 peak to puberty (day) & $136.0 \pm 3.46^{\mathrm{a}}$ & $83.67 \pm 3.45^{\mathrm{b}}$ \\
Interval from first injection to puberty (day) & & \\
At puberty: & $0.36 \pm 0.04$ & $0.41 \pm 0.04$ \\
P4 concentration & $391.0 \pm 3.5^{\mathrm{a}}$ & $341.7 \pm 3.5^{\mathrm{b}}$ \\
Age (day) & $279.1 \pm 18.6$ & $254.6 \pm 12.9$ \\
Live body weight (kg) & $0.46 \pm 0.03$ & $0.47 \pm 0.04$ \\
Overall mean of P4 during the experimental period & & \\
\hline
\end{tabular}

$\mathrm{a}$ and $\mathrm{b}$ : Means having different superscripts within the same row are significantly different at $(\mathrm{P}<0.05)$.

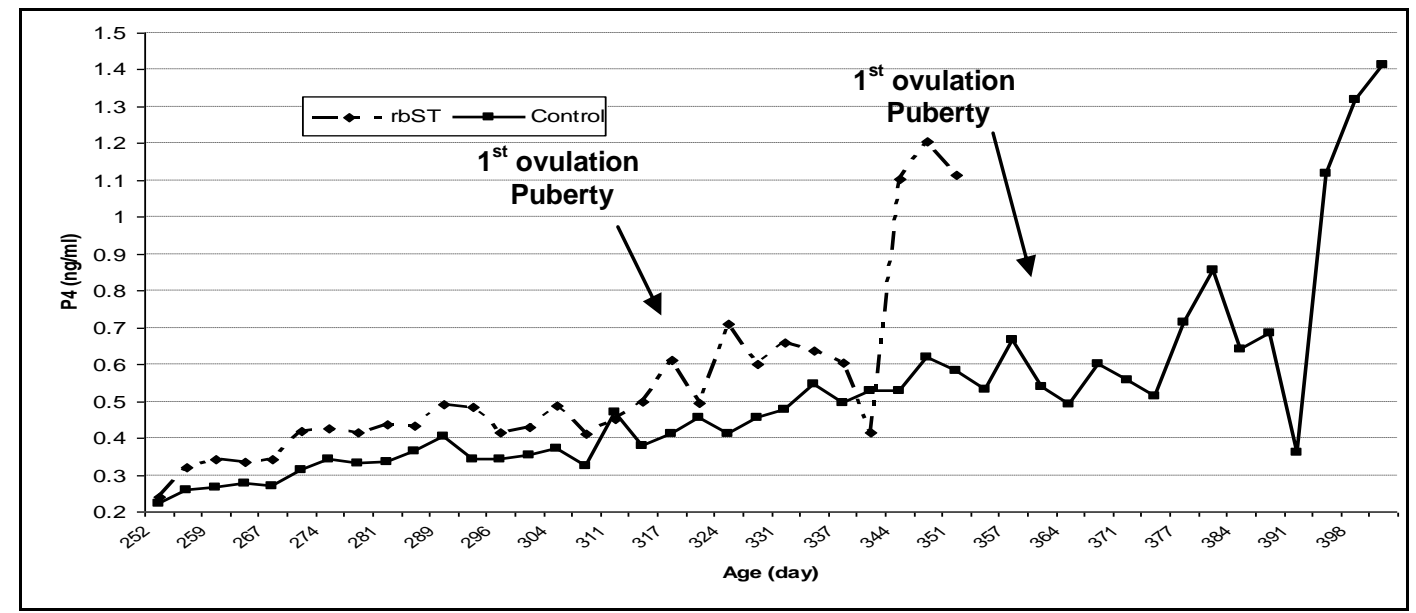

Fig. 1. Plasma P4 concentration in control and treated groups throughout the experimental period measured from rbST injection up to puberty 


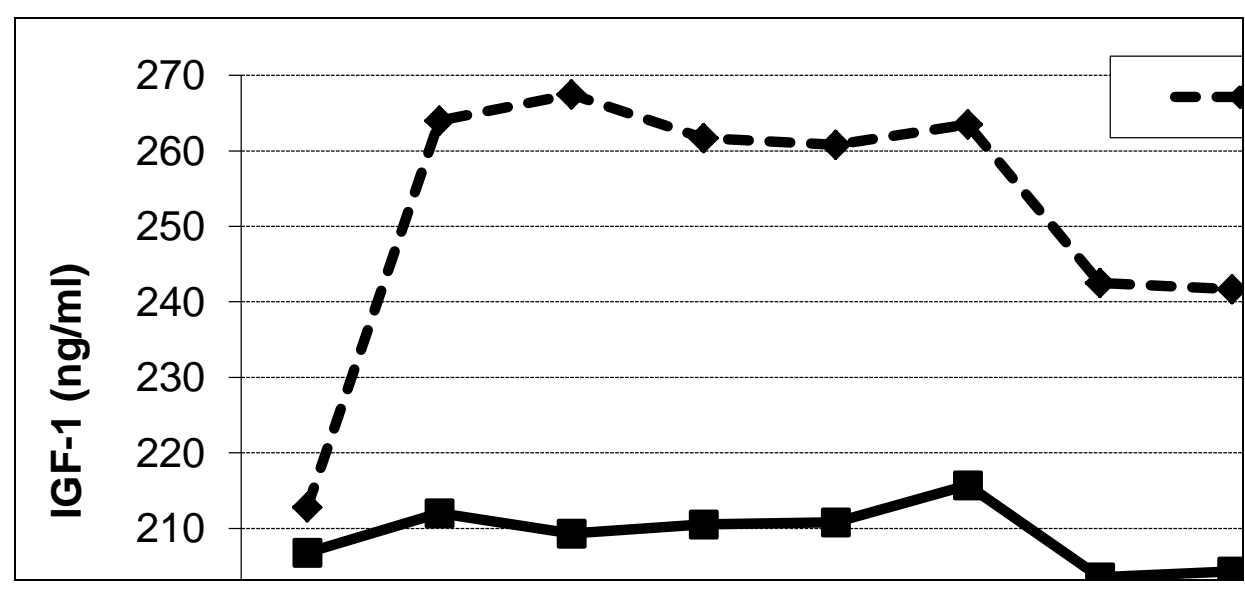

Fig. 2. Change in plasma IGF-I concentration in heifers of control and treated groups throughout the experimental period

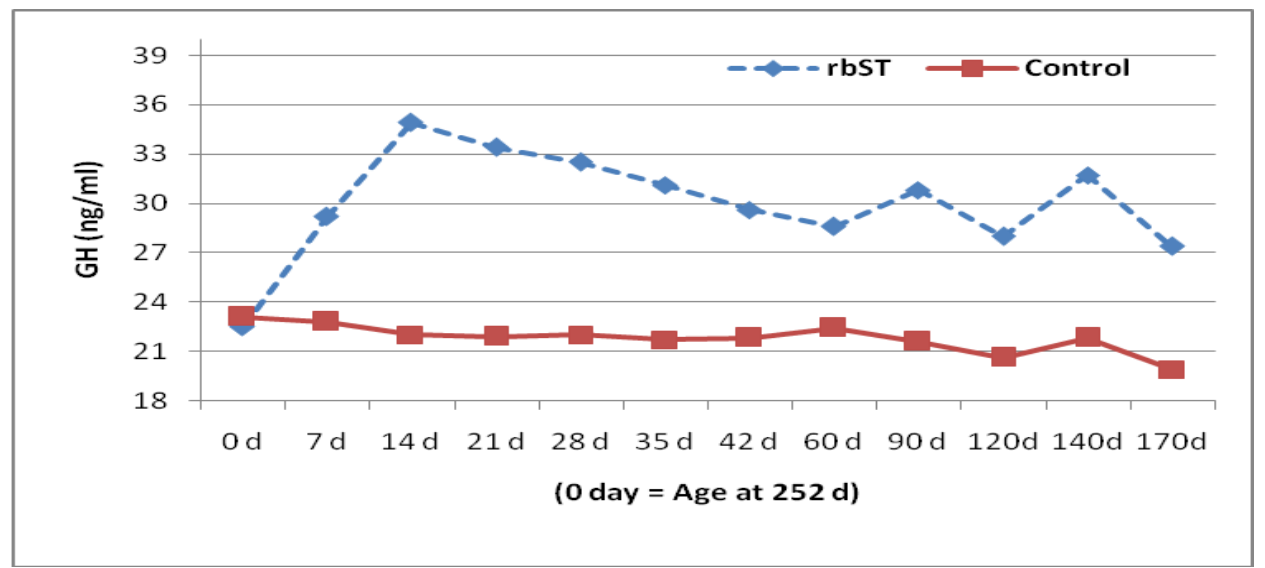

Fig. 3. Change in plasma GH concentration in control and treated groups throughout the experimental period

Table 3. Average concentration of IGF-I and GH (ng/ml) pre- and at puberty in blood plasma of heifers in control (G1) and treated (G2) during the experimental period

\begin{tabular}{llccc}
\hline Item & \multicolumn{1}{c}{ Time } & \multicolumn{1}{c}{ G1 } & G2 & Significance \\
\hline \multirow{2}{*}{ IGF-I } & Pre-puberty $^{(1)}$ & $189.3 \pm 5.4$ & $226.7 \pm 5.4$ & $*$ \\
& At puberty & $204.3 \pm 12.0$ & $242.7 \pm 12.0$ & $*$ \\
& Overall mean & $207.25 \pm 1.9$ & $248.33 \pm 2.4$ & $* * *$ \\
& Pre-puberty & $19.80 \pm 0.57$ & $31.80 \pm 0.57$ & $*$ \\
GH & At puberty & $21.8 \pm 1.5$ & $30.8 \pm 1.5$ & $*$ \\
& Overall mean & $21.80 \pm 0.52$ & $29.98 \pm 0.32$ & $* * *$ \\
\hline
\end{tabular}

* Significant at $\mathrm{P}<0.05 * * *$ Significant at $\mathrm{P}<0.001$. (1): average values of control and treated groups were 8 and $10 \mathrm{wk}$, respectively.

\section{Concentration of glucose and urea- $N$}

Data in Table (4) show that overall concentration of glucose during the experimental period significantly $(\mathrm{P}<0.05)$ increased in $\mathrm{G} 2$ as compared to G1. Although glucose concentration pre- and at puberty was not affected significantly by rbST treatment, it showed different trends of change pre- and at puberty in each group.
On the other hand, concentration of urea-N was significantly lower in G2 than in G1 as overall $(\mathrm{P}<0.001)$ or pre and at puberty $(\mathrm{P}<0.05)$. The reduction in urea- $\mathrm{N}$ concentration was about 15 and $19 \%$ pre- and at puberty, respectively, and may be attributed to variation in live body weight and metabolic status of heifers during pre- and postpuberty. 
As affected by rbST injection, glucose concentration (Figure 4) showed marked increase up to the post $2^{\text {nd }}$ rbst injection in treated group versus marked reduction in control group. However, glucose concentration was higher at puberty in treated than control group, then it increased in control group and still stable in treated group to be similar in both groups at puberty of control group. Such trend suggested incidence of puberty in control group when glucose level reached the same level in treated group. Similar trend of change in glucose level was reported by Gallo and Block (1990), who found that rbst-treatment, resulted in sharp increase in glucose level post-rbst-injection of Friesian cows.

In accordance with the present results, Stevens et al. (1980) reported that glucose values in lactating Holstein cows were $65.2,68.1,65.1$, and 68.6 at rbST levels of $0,10.3,20.6$ and $41.2 \mathrm{mg} / \mathrm{dl}$, while pre-treatment value was 57.1. Also, Pocius and Herbein (1986) stated that glucose concentration was not affected in plasma of Holstein-Friesian cows in mid lactation injected with GH (50 IU/day) for 11 consecutive days. Furthermore, Morbeck et al. (1991) reported that glucose was not influenced by dose of rbST.

In contrast, Molento et al. (2002) found that rbST induced insulin peripheral resistance and increased liver gluconeogenesis, or both. Also, Hall et al. (1994) stated that ST increased circulating concentration of glucose, an effect that may be attributed to increased hepatic gluconeogenesis and reduced uptake of glucose by adipose tissue.

Concerning the results illustrated in Figure (5), plasma urea-N concentrations were almost lower in treated than in control group at all sampling days preand post puberty. It is of interest to note that prepubertal urea-N concentration in heifers showed marked reduction by increasing number of injections, in particular post- ${ }^{\text {st }}$ injection, then urea-N concentration showed slight rise post-puberty. This reduction in urea- $\mathrm{N}$ concentration in treated heifers may be a reflection of decreased amino acid degradation and utilization of these amino acids for increased milk protein synthesis (Marcek et al.,
1989), suggesting that treated animals utilized protein more effectively (Whitaker et al. 1989 and Hodate et al. 1991).

In agreement with the present results, treatment with rbST (640 mg rbST/14d) significantly decreased plasma urea-N concentrations in Holstein heifers (Whitaker et al. 1989 and Hodate et al. 1991). Also, Early et al. (1990) reported that concentrations of serum urea was lower $(\mathrm{P}<0.05)$ in steers (initially 9 mo of age and $231 \pm 18 \mathrm{~kg}$ ) receiving daily injections of rbST $(20.6 \mathrm{mg} / \mathrm{d})$ for $112 \mathrm{~d}$. Moreover, Marcek et al. (1989) found that blood urea-N concentration decreased in pregnant lactating Holstein cows treated with $430 \mathrm{mg} / \mathrm{d}$ of rbST as compared to control cows. On the other point of view, several authors observed insignificant effect of rbST treatment on urea-N in blood of cows (Schams et al., 1991) and primiparous Holstein cows (Morbeck et al., 1991).

Correlation coefficients between each of all parameters studied are presented in Table (5). Results show that GH showed the strongest positive correlation with concentration of IGF-I and negatively correlated with urea-N. Schams et al. (1991) found that concentrations of IGF-I were positively correlated with changes in ST. Such results may indicate the important role of exogenous ST on increasing concentration of IGF-I as a metabolic mediator involved in the initiation of puberty in heifers (Simpson et al., 1991).

It is of interest to note that the correlation between concentration was positive between IGF-I and glucose $(\mathrm{r}=0.314, \mathrm{P}<0.001)$ and negative with urea-N $(0.314, \quad \mathrm{P}<0.001)$. The present results indicated poor positive correlation between $\mathrm{P} 4$ concentration and each of IGF-I, GH, and urea-N, while P4 concentration negatively correlated $(\mathrm{P}<0.01)$ with glucose concentration.

In conclusion, rbST treatment at a level of 250 $\mathrm{mg}$ at 14- day interval for five times pre-puberty is strongly in relation to concentration of ST and IGF-I and in less extend to glucose and urea-N concentration to induce precocious puberty in Friesian heifers.

Table 4. Concentration of glucose and urea-N $(\mathrm{X} \pm \mathrm{SE})$ as measured pre- and at puberty in blood plasma of heifers in control (G1) and treated (G2) groups

\begin{tabular}{|c|c|c|c|c|}
\hline Item & Time & G1 & G2 & Significance \\
\hline \multirow{3}{*}{$\begin{array}{l}\text { Glucose } \\
\text { (mg/dl) }\end{array}$} & Pre-puberty & $75.21 \pm 3.92$ & $86.23 \pm 3.92$ & NS \\
\hline & At puberty & $81.68 \pm 3.25$ & $80.73 \pm 3.25$ & NS \\
\hline & Overall mean & $79.10 \pm 1.2$ & $85.86 \pm 1.3$ & $*$ \\
\hline \multirow{3}{*}{$\begin{array}{l}\text { Urea-N } \\
\text { (mg/dl) }\end{array}$} & Pre-puberty & $33.23 \pm 1.08$ & $28.33 \pm 1.08$ & $*$ \\
\hline & At puberty & $31.70 \pm 1.54$ & $25.53 \pm 1.54$ & $*$ \\
\hline & Overall mean & $27.48 \pm 0.86$ & $32.16 \pm 0.92$ & $* * *$ \\
\hline
\end{tabular}




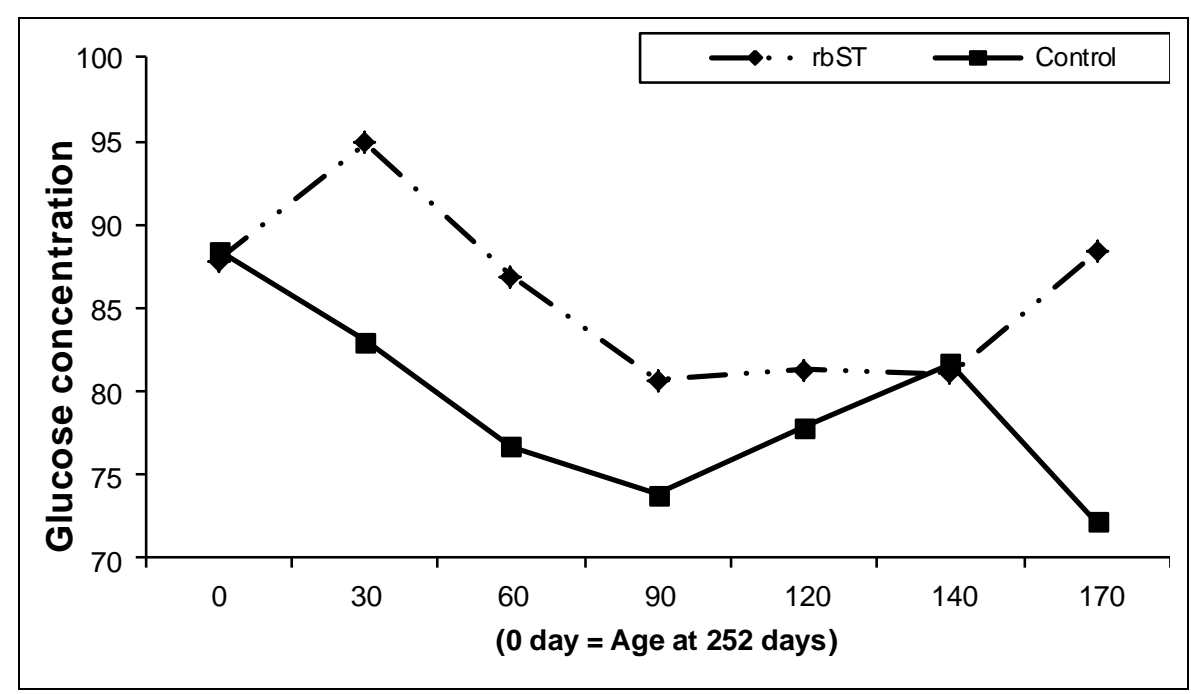

Fig. 4. Plasma glucose concentration before ( 0 day) and after rbST treatment in control and treated groups

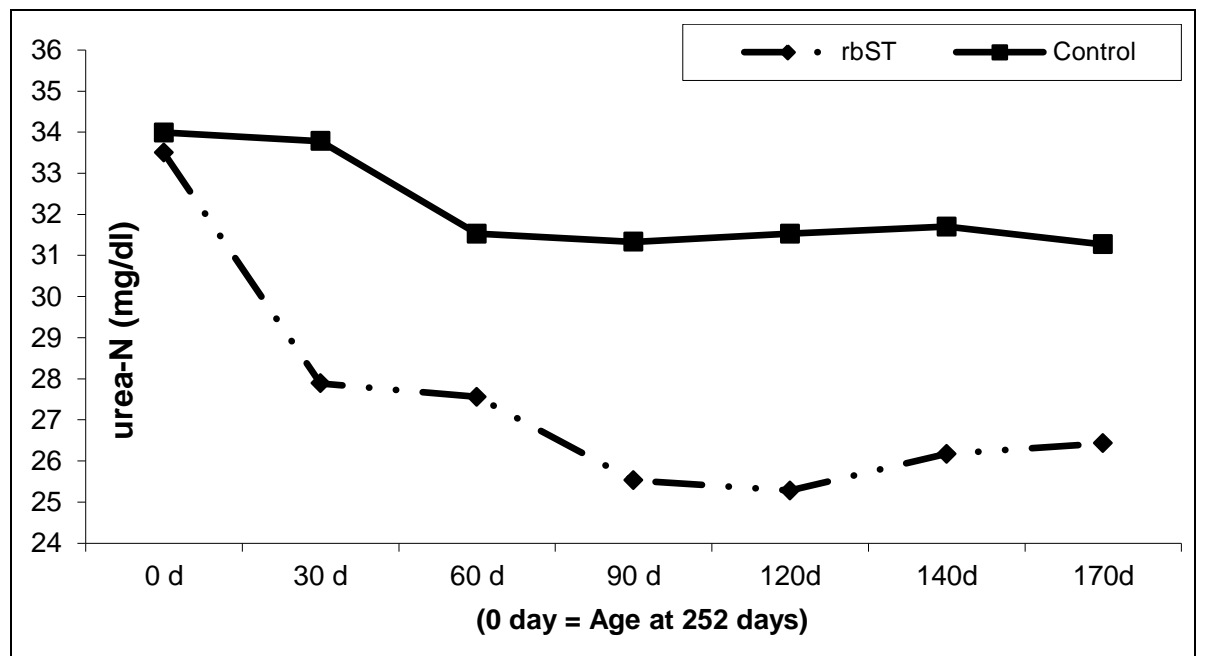

Fig. 5. Change in plasma urea-N concentration in heifers of treated and control groups throughout the experimental period

Table 5. Pearson correlation coefficients between different parameters studied in both treated and control groups

\begin{tabular}{lcccc}
\hline Item & IGF-I & GH & P4 & Urea-N \\
\hline GH & $0.69560^{* * *}$ & & & \\
P4 & $0.06175^{\mathrm{NS}}$ & $0.15344^{\mathrm{NS}}$ & & \\
Urea-N & $-0.21743^{*}$ & $-0.18888^{*}$ & $-0.08411^{\mathrm{NS}}$ & \\
Glucose & $0.31459^{* * *}$ & $0.16080^{\mathrm{NS}}$ & $-0.27330^{* *}$ & $-0.22963^{*}$ \\
\hline
\end{tabular}

NS: Not significant * Significant at $\mathrm{P}<0.05 * *$ Significant at $\mathrm{P}<0.01 * *$ Significant at $\mathrm{P}<0.001$

\section{REFERENCES}

A.O.A.C., 1995. Official Methods of Analysis $15^{\text {th }}$ ed. Association of Official Analytical Chemists. Arlington, Virginia, USA.

Aboul-Wafa, Heba A., 2009. Improving reproductive performance of sheep using rbST. M. Sc. Thesis, Fac. Agric. Mansoura Univ., Egypt.

Adashi, E.Y., C. Resnick, E.R. Hemsndcz, M.E. Svoboda, E. Hohf, D.R. Clemmm, P.K. Lund and I.J. Van Wyk, 1989. Rodent studies on the potential relevance of insulin-like growth factor (IGF-1) to ovarian physiology. In: A. N. Hirschfield (Ed.). Growth Factor and the Ovary. Plenum Press, New York, USA.

Chandrashekar, V., D. Zaczek and A. Bartke, 2004. The consequences of altered somatotropic system on reproduction. Biology of Reproduction, 71:17-27.

Crooker, B.A., M.A. McGuire, W.S. Cohick, M. Harkins, D.E. Bauman, and K. Sejrsen ,1990. 
Effect of dose of bovine somatotropin on nutrient utilization in growing dairy heifers. Journal of Nutrition, 120:1256.

Daughaday, W.H. and P. Rotwein, 1989. Insulin-like growth factor-I and II, peptide, messenger ribonucleic acid and gene structures, serum and tissue concentrations. Endocrine Reviews, 10 (1): 68-91.

Dodson, S.E., B.J. Mcleod, W. Haresign, A.R. Peters, and G.E. Lamming, 1988. Endocrine changes from birth to puberty in the heifer. Journal of Reproduction and Fertility, 82:527-538.

Early, R.J., B.W. McBride, and R.O. Ball, 1990.Growth and metabolism in somatotropintreated steers: I. Growth, serum chemistry and carcass weights. Journal of Animal Science, 68:4134-4143.

Gallo, G.F. and E. Block, 1991. Effects of recombinant bovine somatotropin on hypophyseal and ovarian functions of lactating dairy cows. Canadian Journal of Animal Science, 71:343-353.

Gallo, G.F. and E. Block, 1990. Effect of recombinant bovine somatotropin on nutritional status and liver function of lactation dairy cows. Journal of Dairy Science, (11): 3276-86.

Hall, J.B., K.K. Schillo, B.P. Fitzgerald and N.W. Bradley, 1994.Effects of recombinant bovine somatotropin and dietary energy intake on growth, secretion of luteinizing hormone, follicular development, and onset of puberty in beef heifers. Journal of Animal Science, 72:709-718.

Hodate, K., A. Ozawa and T. Johke, 1991. Effect of a prolonged release formulation of recombinant bovine somatotropin on plasma concentrations of hormones and metabolites and milk production in dairy cows. Endocrinologia Japonica Nihon Naibunpi Gakkai, 38 (5):527-532. (Abstr.).

Hsu, C.J. and J.M. Hammond, 1987. Concomitant effects of growth hormone on secretion of insulinlike growth factor-I and progesterone in cultured porcine granulosa cells. Endocrinology, 121:13431348.

Jones, E.J., J.D. Armstrong and R.W. Harvey, 1991.Changes in metabolites, metabolic hormones and luteinizing hormone before puberty in Angus, Braford, Charolais, and Simmental heifers. Journal of Animal Science, 69:1607-1616.

Kirkwood, R.N., P.A. Thacker, A.D. Gooneratne, B.L. Guedo and B. Laarveld ,1988. The influence of exogenous growth hormone on ovulation rate in gilts. Canadian Journal of Animal Science, 68:1097-1103.

Lucy, M.C., 2000. Regulation of ovarian follicular growth by somatotropin and insulin-like growth factors in cattle. Journal of Dairy Science, 83:1635-1647.

Lucy, M.C., J.C. Byatt, T.L. Curran, D.F. Curran and R.J. Collier, 1994. Placental lactogen and somatotropin hormone binding to the corpus luteum and effects on the growth and functions of the ovary in heifers. Biology of Reproduction, 50:561-572.

Marcek, J.M., W.J. Seaman and J.L. Nappier ,1989. Effects of repeated high dose administration of recombinant bovine somatotropin in lactating dairy cows. Veterinary \& Human Toxicology, 31:455-460.

McShane, T.M., K.K. Scillo, J.A. Boling, N.W. Bradley and J.B. Hall, 1989.Effects of recombinant-DNA derived somatotropin and dietary energy intake on development of beef heifers: I. Growth and puberty. Journal of Animal Science, 67:2230-2236.

Mejia, M., A. Gonzalez-Iglesias, G.S. Diaz-Torga, P. Villafane, N. Formia, C. Libertun, D. BecuVillalobos and I.M. Lacau-Mengido ,1999. Effects of continuous ivermectin treatment from birth to puberty on growth and reproduction in dairy heifers. Journal of Animal Science, 77:13291334.

Molento, C.F.M., E. Block, R.I. Cue and D. Peticlerc, 2002. Effects of insulin, recombinant bovine somatotropin, and their interaction on insulin-like growth factor-I secretion and milk production in dairy cows. Journal of Dairy Science, 85:738-747.

Morbeck, D.E., J.H. Britt and B.T. McDaniel, 1991. Relationships among milk yield, metabolism, and reproductive performance of primiparous Holstein cows treated with somatotropin. Journal of Dairy Science, 74:2153-2164.

Moseley, W.M., J.B. Paulissen, M.C. Goodwin, G.R. Alaniz and W.H. Claflin, 1992. Recombinant bovine somatotropin improves growth performance in finishing beef steers. Journal of Animal Science, 70:412-425.

NRC, 2001. Nutrient Requirement of Dairy Cattle. ( $7^{\text {th }}$ Ed), National Academy Press. Washington. D.C., USA.

Ojeda S.R. and H.E. Jameson, 1977. Developmental patterns of plasma and pituitary growth hormone in the female rat. Endocrinology, 100:881-889.

Patton, C.J. and S.R. Crouch ,1977. Determination of urea-N in blood. Analytical Chemistry, 49: 464469.

Pocius, P.A. and J.H. Herbein, 1986. Effects of in vivo administration of growth hormone on milk production and in vitro hepatic metabolism in dairy cattle. Journal of Dairy Science, 69:713720.

Rausch, M.I., M.W. Tripp, K.E. Govoni, W. Zang, W.J. Weber, B.A. Crooker, T.A. Hoagland and S. A. Zinn, 2002. The influence of level of feeding on growth and serum insulin-like growth factor-1 and insulin-like growth factor binding proteins in growing beef cattle supplemented with somatotropin. Journal of Animal Science, 80:94100.

Sandles, L.D. and C.I. Peel, 1987. Growth and carcass composition of prepubertal dairy heifers 
treated with bovine growth hormone. Animal Production, 44:21-27.

SAS ,2004.SAS / Stat, SAS User's Guide: Version 9.1.3. SAS Institute, Cary, NC.

Schams, D., F. Graf, B. Graule, M. Abele and S. Prokopp, 1991. Hormonal changes during lactation in cows of three different breeds. Livestock Production Science, 27:285-296.

Schlegel, M.L., W.G. Bergen, A.L. Schroeder, M.J. VandeHaar and S.R. Rust, 2006. Use of bovine somatotropin for increased skeletal and lean tissue growth of Holstein steers. Journal of Animal Science, 84:1176-1187.

Simpson, R.B., J.D. Armstrong, R.W. Harvey, D.C. Miller, E.P. Heimer and R.M. Campbell, 1991. Effect of active immunization against growth hormone-releasing factor on growth and onset of puberty in beef heifers. Journal of Animal Science, 69:4914-4924.

Skaar, T.C., C.R. Baumrucker; D.R. Deaver and J.W. Blum,1994. Diet effects and ontogeny of alterations of circulating insulin-like growth factor binding proteins in newborn dairy calves. Journal of Animal Science, 72: 421-432.

Slaba, J., P. Krejci, L.M. Huybrechts, E. Decuypere and H. Herrmann, 1994. Plasma profiles of somatotropin and IGF-I in dairy cows following application of two preparations of recombinant bovine somatotropin in a sustained release vehicle. Physiological Research, 43 (1):37-43.

Snedecor, G.W. and W.G. Cochran, 1982. Statistical Methods. $7^{\text {th }}$ Ed. Iowa State Univ. Press, Ames. Iowa, USA.

Spicer, L.J., J. Klindt, R. Maurer, F.C. Buonomo and S.E. Echtemkamp, 1990. Effect of porcine somatotropin (pST) on number of granulosa cell
$\mathrm{LH} / \mathrm{hCG}$ receptor, oocyte viability and concentration of progesterone $(\mathrm{P})$ and insulin-like growth factor-I (IGF-1) in follicular fluid (FFL) of lean and obese gilts. Journal of Animal Science, 68:410-421.

Stelwagen, K.; D.G. Grieve, J.S. Walton, J.L. Ball and B.W. McBride ,1993. Effect of prepartum bovine somatotropin in primigravid ewes on mammogenesis, milk production and hormone concentrations. Journal of Dairy Science, 76:9921001.

Stevens, J.B, J.F Anderson, W.G. Olson and J.C. Schlatthauer, 1980. Metabolic profile testing. In Bovine Medicine and Surgery. H. E. Amstutz, ed. Am. Vet. Pupl. Inc., Santa Barbara, CA, USA, pp597-599.

Trinder, P. 1969. Determination of blood serum glucose. Annual Clinical Biochemistry, 6, 24-25.

Tripp, M.W., T.A. Hoagland, G.E. Dahl, A.S. Kimrey and S.A. Zinn, 1998. Methionine and somatotropin supplementation in growing beef cattle. Journal of Animal Science, 76:1197-1203.

Van Wyk, J. J., 1983. Diagnosis of growth hormone deficiency and other causes of growth failure. The Endocrine Society, Syllabus for the $35^{\text {th }}$ Annual Postgraduate Assembly pp. 90-106.

Vestergaard, M., K. Sejrsen, J. Foldager, S. Kastrup and D.E. Bauman, 1993. The effect of bovine growth hormone on growth, carcass composition, and meat quality of dairy heifers. Animal Science, 43:165-172.

Whitaker, D.A., E.J. Smith and J.M. Kelly, 1989. Milk production, weight changes and blood biochemical measurements in dairy cattle receiving recombinant bovine somatotropin. Veterinary Record, 124:83- 86. 
تأثير هرمون النمو المخلق وراثيا علي عمر البلوغ و بعض صفات الدم في عجلات الفريزيان

شريف عبد الونيس جبر

قسم الإنتاج الحيو/نس، كلية الزراعة، جامعة طنطا جئل

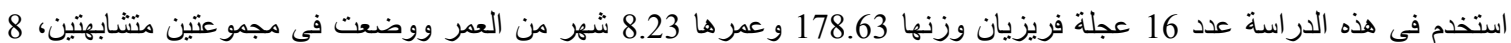

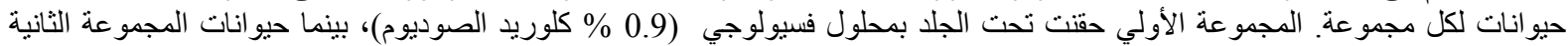

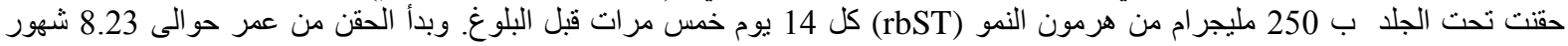

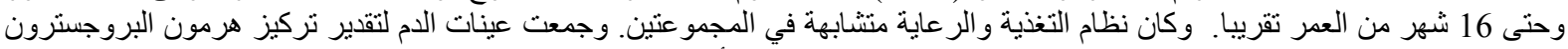

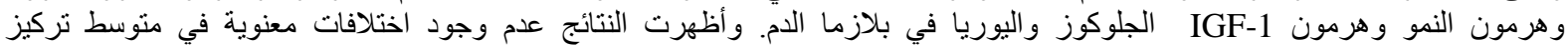

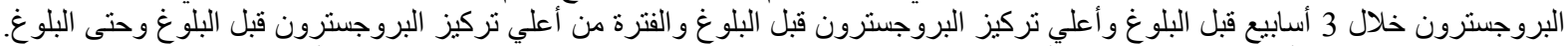

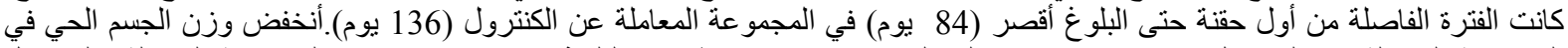

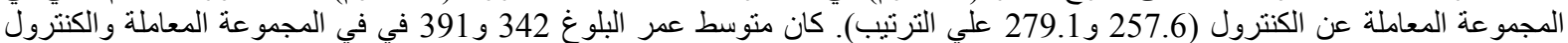

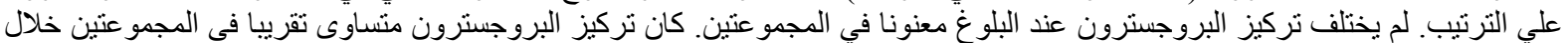

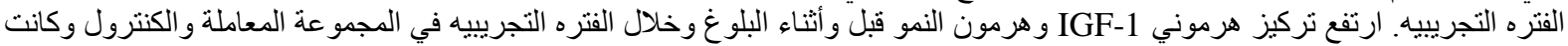

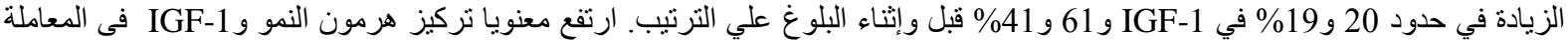

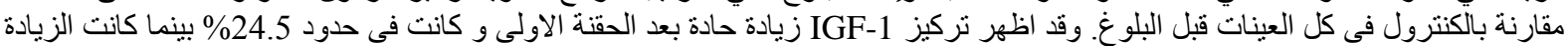

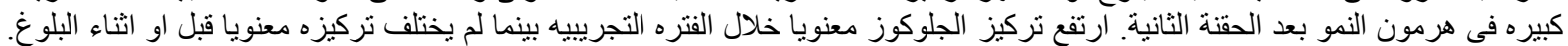

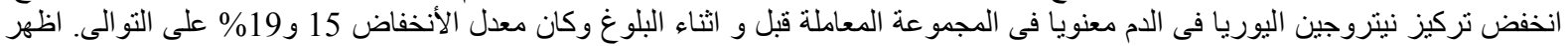

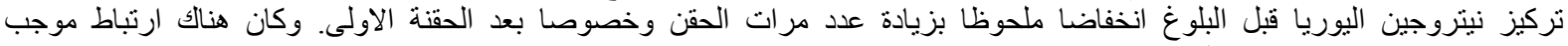

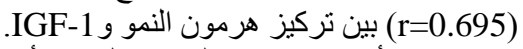

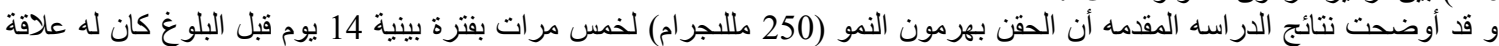
قوية لرفع مستوى هرمون النمو و التور وGF-1 وبدرجه اقل مع مستوى الجلوكوز و اليوريا فى التبكير بحدوث البلوغ لعجلات الفريزيان. 